Sławomir OBERZIG ${ }^{1}$, Arkadiusz TRĄBKA ${ }^{2}$

Opiekun naukowy: Arkadiusz TRĄBKA ${ }^{2}$

DOI: https://doi.org/10.53052/9788366249837.18

\title{
ANALIZA WYTRZYMAŁOŚCIOWA RAMY NOŚNEJ POJAZDU TERENOWEGO O NAPĘDZIE ELEKTRYCZNYM
}

\begin{abstract}
Streszczenie: Przedstawiono modele geometryczny i obliczeniowy projektowanej ramy przestrzennej jednoosobowego pojazdu terenowego o napędzie elektrycznym. Analizy numeryczne przeprowadzono $\mathrm{w}$ programie FEMAP dla sześciu wariantów obciążenia stanowiących odwzorowanie sił przekazywanych na konstrukcję podczas jazdy w warunkach terenowych. Analizy przeprowadzono w celu sprawdzenia wytrzymałości oraz sztywności projektowanej konstrukcji.
\end{abstract}

Słowa kluczowe: analiza wytrzymałościowa, metoda elementów skończonych, rama przestrzenna, pojazd terenowy o napędzie elektrycznym

\section{STRENGTH ANALYSIS OF THE CARRIER FRAME OF THE OFF-ROAD ELECTRIC VEHICLE}

Summary: The geometrical and computational models of a one-person off-road electric vehicle newly designed spatial frame are presented. Numerical analyses were performed using the FEMAP software. Six load variants representing forces transferred to the structure while driving in off-road conditions were considered. The analyses were carried out to verify the strength and stiffness of the designed structure.

Keywords: strength analysis, finite element method, spatial frame, off-road electric vehicle

\section{Wprowadzenie}

Struktury nośne pojazdów mogą występować jako bezramowe, tzw. samonośne oraz jako ramowe. O wyborze typu struktury nośnej decydują warunki, w których dany pojazd będzie eksploatowany oraz czynniki ekonomiczne. W przypadku pojazdów terenowych strukturę nośną stanowią najczęściej tzw. ramy niezależne typu

1 Akademia Techniczno-Humanistyczna w Bielsku-Białej, Wydział Budowy Maszyn i Informatyki, specjalność: Komputerowe Wspomaganie Konstruowania i Wytwarzania, oberzigs@gmail.com

${ }^{2}$ dr. inż., Akademia Techniczno-Humanistyczna w Bielsku-Białej, Wydział Budowy Maszyn i Informatyki, atrabka@ath.bielsko.pl 
podłużnicowego [1]. Ramy te przenoszą obciążenia pochodzące zarówno od podłoża jak i od nadwozia, zatem dla uzyskania wymaganej wytrzymałości oraz sztywności muszą być wykonywane z kształtowników o dużych przekrojach poprzecznych, a zarazem znacznej masie. W przypadku pojazdów terenowych o napędzie elektrycznym, gdzie z uwagi na dodatkową masę pochodzącą od akumulatorów struktura nośna powinna być jak najlżejsza, lepszym wyborem może okazać się tzw. rama zespolona typu kratownicowego (rama przestrzenna). Ramy tego typu dotychczas stosowano głównie w budowie samochodów wyścigowych oraz sportowych [2].

W niniejszej pracy przedstawiono modele geometryczny i obliczeniowy projektowanej ramy przestrzennej jednoosobowego pojazdu terenowego o napędzie elektrycznym, a następnie sprawdzono, czy pod względem wytrzymałościowym konstrukcję można uznać za prawidłowo zaprojektowaną.

\section{Projekt koncepcyjny i model obliczeniowy ramy}

Kształt oraz wymiary projektowanej ramy przestrzennej (wykonanej z zamkniętych profili cienkościennych o przekroju kwadratowym 30x30x3) dobrano w taki sposób, aby zapewnić kierowcy możliwie dużą swobodę oraz wygodę. W projekcie uwzględniono tzw. kąty wygody dla pozycji siedzącej w samochodzie (kąty, pod jakimi powinny być ułożone poszczególne części ciała kierowcy) zawarte w normie DIN 33408 [3]. Zarazem, podczas kształtowania ramy brano pod uwagę możliwość uzyskania jak największych wartości kątów natarcia i zejścia oraz kąta rampowego, a także prześwitów - poprzecznego i podłużnego. Na tej podstawie wykonano szkice pojazdu (rys. 1a), a następnie model geometryczny ramy (rys. 1b).

a)

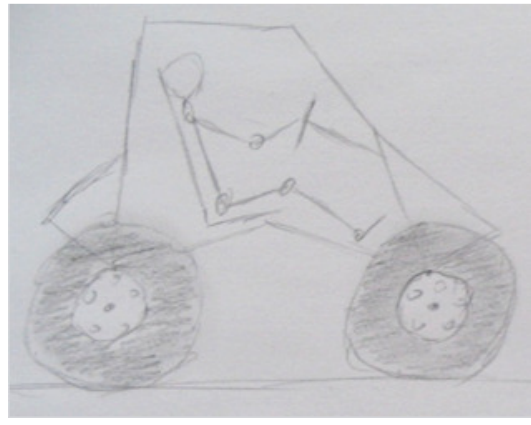

b)

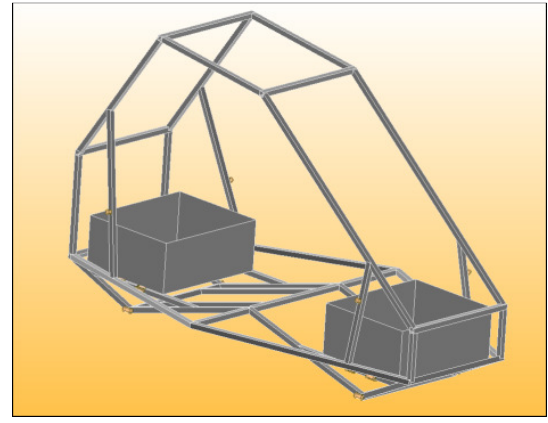

Rysunek 1. Projekt koncepcyjny: a) szkic pojazdu, b) model geometryczny ramy nośnej

W modelu geometrycznym, który wykonano w programie Autodesk Inventor, uwzględniono wsporniki wahaczy i amortyzatorów, prowadnice fotela oraz skrzynie na akumulatory. Akumulatory zdecydowano się umieścić zarówno z przodu jak i z tyłu pojazdu, tak aby uniknąć nadmiernego dociążenia tylko jednej osi, a zarazem uzyskać centralne położenie jego środka ciężkości. W celu wstępnej weryfikacji poprawności projektu model ramy uzupełniono o elementy zawieszenia, koła z silnikami oraz fotel z zarysem sylwetki kierowcy (rys. 2). 


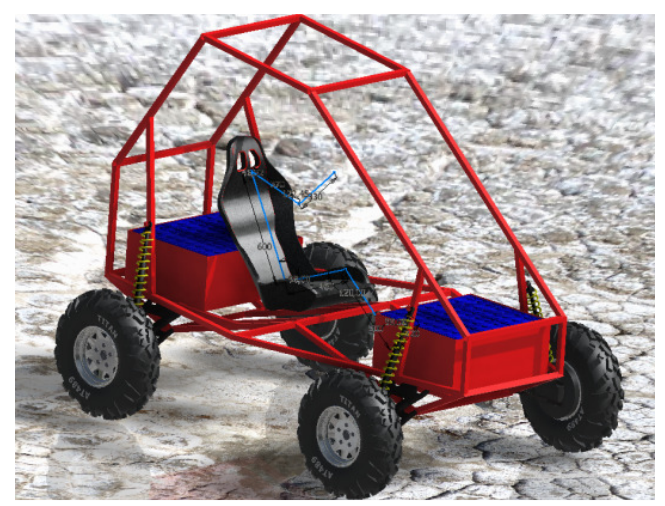

Rysunek 2. Rama z rozmieszczeniem wspótpracujących elementów

Model obliczeniowy (rys. 3a) wykonano w programie metody elementów skończonych FEMAP. Ramę oraz skrzynie na akumulatory poddano dyskretyzacji przy użyciu elementów powłokowych, natomiast wsporniki elementów zawieszenia (wahaczy i amortyzatorów) opisano elementami bryłowymi [4]. Wahacze przedstawiono w modelu obliczeniowym jako nieodkształcalne elementy belkowe natomiast amortyzatory jako elementy sprężysto-tłumiące (rys. 3a). Połączenie elementów zawieszenia $\mathrm{z}$ ramą zrealizowano za pośrednictwem tzw. pęku sztywnych elementów belkowych (rys. 3b).

a)

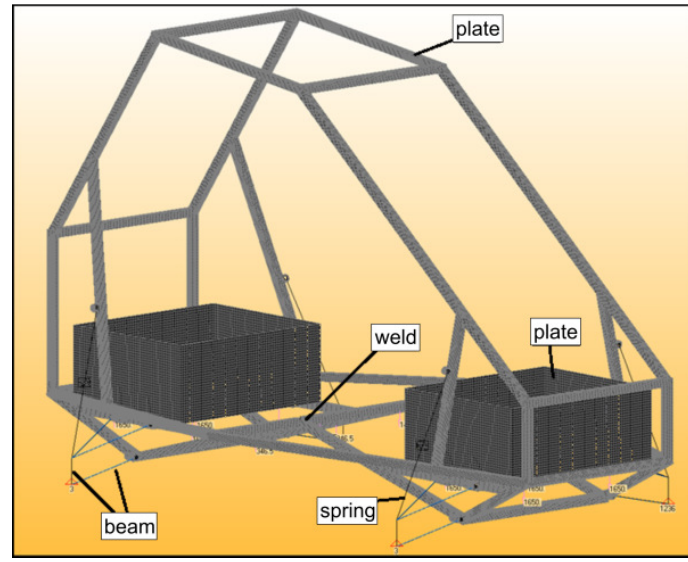

Rysunek 3. a) model obliczeniowy ramy wraz z elementami zawieszenia, b) połaczenie wahacza z rama za pośrednictwem tzw. pęku belek

\section{Warunki brzegowe i dobór obciążeń}

Podparcie modelu obliczeniowego na etapie analizy wytrzymałości konstrukcji zrealizowano przez wprowadzenie więzów w miejscach połączeń elementów zawieszenia z kołami, natomiast dla analizy sztywności konstrukcji wprowadzono więzy w miejscach połączeń górnych wsporników z elementami zawieszenia $[4,5]$. 
Do modelu wprowadzono obciążenia statyczne:

- $\quad$ od ciężaru akumulatorów (2 x $1650 \mathrm{~N})$;

- $\quad$ od ciężaru fotela $(90 \mathrm{~N})$ oraz kierowcy $(900 \mathrm{~N})$, rozłożone na 4 wektory sił oddziałujące na prowadnice fotela w proporcjach 70\% tył, 30\% przód.

Efekt oddziaływań dynamicznych uzyskano poprzez zwielokrotnienie wartości obciążeń statycznych [6,7]. W tym celu wprowadzono do modelu przyspieszenia pionowe występujące przy tzw. dobiciu zawieszenia podczas jazdy w warunkach terenowych $(4 \mathrm{~g})$ oraz opóźnienia poziome rejestrowane przy gwałtownym hamowaniu (1g). Dobierając wartości przyspieszeń korzystano $\mathrm{z}$ informacji zamieszczonych w pracy [1]. Przy braku obciążeń dynamicznych przyjęto, że na pojazd działa przyspieszenie ziemskie $9.81 \mathrm{~m} / \mathrm{s}^{2}(1 \mathrm{~g})$.

Oprócz wymuszeń siłowych w modelu stosowano także wymuszenia kinematyczne, np. zadając przemieszczenie pionowe punktu podparcia, w celu odwzorowania sytuacji najechania kołem na przeszkodę. Na podstawie informacji zamieszczonych w [1] przyjęto, że maksymalna wysokość przeszkody podczas jazdy w warunkach terenowych może wynosić $400 \mathrm{~mm}$.

Miejsca przyłożenia sił do modelu obliczeniowego, wartości i kierunki wektorów przyspieszeń oraz rodzaje pokonywanych przeszkód zamieszczono w tabeli 1.

Tabela 1. Warianty obciążén modelu obliczeniowego

\begin{tabular}{|c|c|c|c|}
\hline Wariant/opis & Schemat & Wariant/opis & Schemat \\
\hline $\begin{array}{c}\text { A } \\
\text { Jazda po } \\
\text { płaskiej } \\
\text { powierzchni }\end{array}$ & & $\begin{array}{c}\text { B } \\
\text { Zjazd z } \\
\text { krawężnika }\end{array}$ & \\
\hline $\begin{array}{c}\text { C } \\
\text { Przejazd } \\
\text { ukosem przez }\end{array}$ & & $\begin{array}{c}\text { D } \\
\text { Najazd kołem } \\
\text { na przeszkodę }\end{array}$ & \\
\hline $\begin{array}{c}\text { E } \\
\text { Jazda z dużą } \\
\text { prędkością po } \\
\text { nierównościach }\end{array}$ & & $\begin{array}{c}\text { F } \\
\text { Hamowanie } \\
\text { podczas jazdy } \\
\text { po } \\
\text { nierównościach }\end{array}$ & \\
\hline
\end{tabular}




\section{Analiza wytrzymałości i sztywności projektowanej ramy}

Analizy numeryczne przeprowadzono w programie FEMAP. W pierwszej kolejności dla każdego wariantu obciążeń wykonano obliczenia naprężeń zredukowanych (według hipotezy Hubera-Misesa-Henky'ego), a następnie porównano ich maksymalne wartości. Na rysunkach 4-6 przedstawiono wybrane wyniki analiz odpowiadające obciążeniom oddziałującym na konstrukcję podczas jazdy w warunkach terenowych, takich jak chwilowa utrata kontaktu jednego z kół z podłożem (rys. 4), najazd kołem na przeszkodę (rys. 5), gwałtowne hamowanie podczas jazdy po nierównościach (rys. 6).

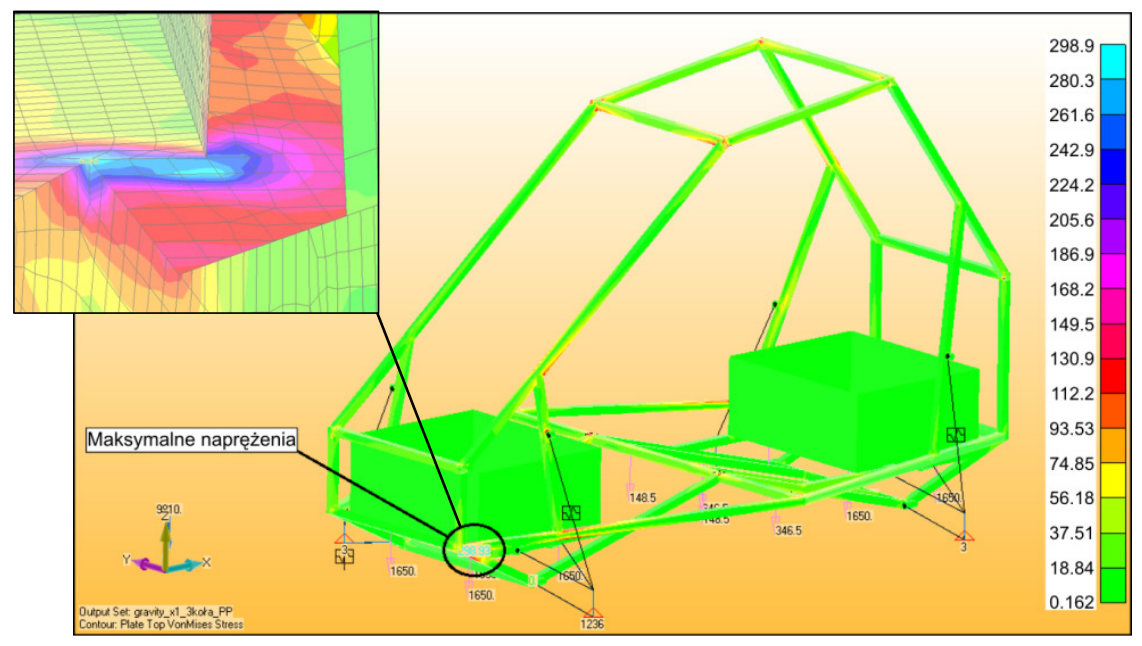

Rysunek 4. Rozkład naprężén zredukowanych dla wariantu B (zjazd z krawężnika)

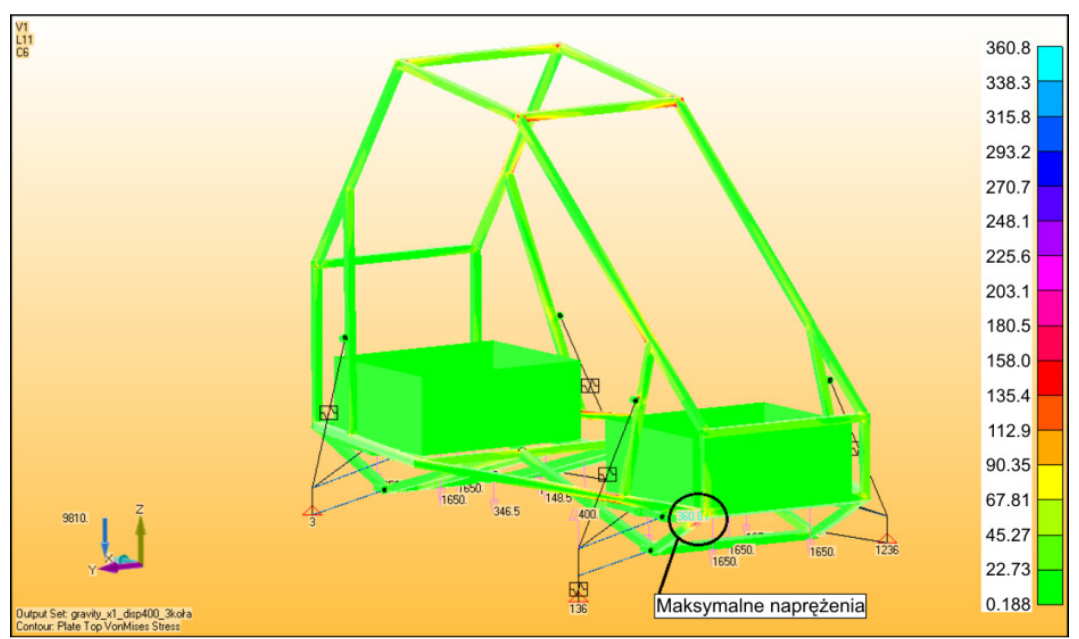

Rysunek 5. Rozkład naprężeń zredukowanych dla wariantu D (najazd kołem na przeszkodę) 


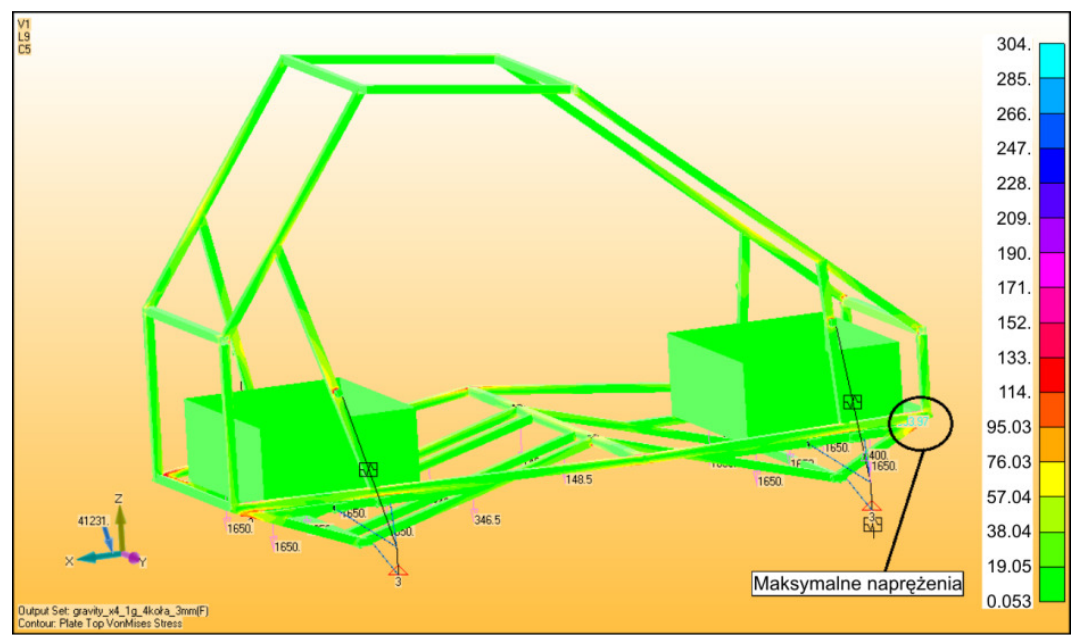

Rysunek 6. Rozkład naprężeń zredukowanych dla wariantu F (hamowanie podczas jazdy po nierównościach)

Analizując wartości maksymalnych naprężeń zredukowanych dla wszystkich wariantów obciążeń i profili o grubości ścianek $3 \mathrm{~mm}$ (tabela 2) zauważono, że w większości przypadków została przekroczona wartość naprężeń dopuszczalnych $\mathrm{k}_{\mathrm{dop}}=271 \mathrm{MPa}$, które dla stali S460MLH o granicy plastyczności $\mathrm{Re}=460 \mathrm{MPa}$ otrzymano dla współczynnika bezpieczeństwa $\mathrm{n}=1.7$ (wartość spełniająca kryteria wysokocyklowej wytrzymałości zmęczeniowej [8]). Z uwagi na to, że rama nie spełniała kryteriów wysokocyklowej wytrzymałości zmęczeniowej, podjęto decyzję o zwiększeniu grubości ścianek użytych do jej wykonania profili z $3 \mathrm{~mm}$ do $4 \mathrm{~mm}$. Wartości maksymalnych naprężeń zredukowanych dla wszystkich wariantów obciążeń i ścianek profili o grubości $4 \mathrm{~mm}$ zamieszczono w tabeli 2.

Tabela 2. Maksymalne naprężenia zredukowane dla poszczególnych wariantów obciążeń i grubości ścianek profili użytych do wykonania ramy nośnej pojazdu

\begin{tabular}{|c|c|c|c|c|c|c|}
\hline \multirow{3}{*}{$\begin{array}{l}\text { Grubości } \\
\text { ścianek profili } \\
\text { ramy }\end{array}$} & \multicolumn{6}{|c|}{ Wariant obciążenia } \\
\hline & A & B & $\mathrm{C}$ & $\mathrm{D}$ & $\mathrm{E}$ & $\mathrm{F}$ \\
\hline & \multicolumn{6}{|c|}{ Maksymalne naprężenia zredukowane [MPa] } \\
\hline $3 \mathrm{~mm}$ & 190 & 299 & 337 & 361 & 312 & 304 \\
\hline $4 \mathrm{~mm}$ & 141 & 227 & 259 & 263 & 247 & 233 \\
\hline
\end{tabular}

Wartości maksymalnych naprężeń zredukowanych otrzymane po zwiększeniu grubości ścianek profili użytych do wykonania ramy nośnej świadczą o tym, że pod względem wytężeniowym konstrukcja nośna pojazdu została prawidłowo zaprojektowana. 
Analizę sztywności ramy nośnej pojazdu przeprowadzono dla profili o grubości ścianek wynoszącej $4 \mathrm{~mm}$. Aby ustalić jakich deformacji doznaje konstrukcja, dla każdego $\mathrm{z}$ rozpatrywanych wariantów obciążeń wyznaczono wypadkowe przemieszczenia wyłącznie węzłów ramy, tzn. bez uwzględnienia pracy zawieszenia. W tym celu dokonano podparcia ramy w miejscach połączeń górnych wsporników z elementami zawieszenia (rys. 7). Oddziaływanie elementów zawieszenia na ramę uwzględniono poprzez przyłożenie $\mathrm{w}$ poprzednich punktach podparcia, tzn. w węzłach łączących elementy zawieszenia z kołami, obciążeń o wartościach równych siłom reakcji w tych punktach.

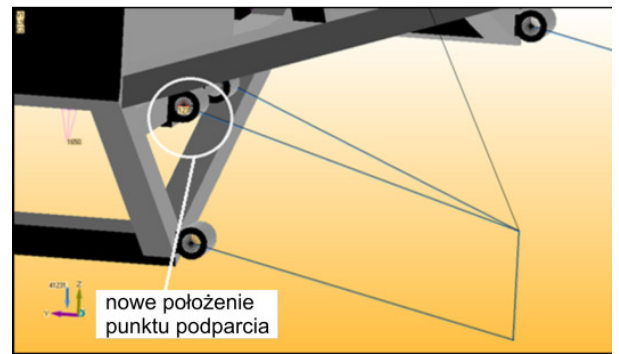

Rysunek 7. Lokalizacja punktów podparcia modelu ramy do analizy przemieszczeń

Na kolejnych rysunkach przedstawiono wyniki analiz dla tych samych wariantów obciążeń, dla których pokazano warstwice naprężeń zredukowanych. Na rysunku 8 przedstawiono wypadkowe przemieszczenia węzłów oraz wskazano miejsce wystąpienia maksymalnej deformacji pojedynczego profilu ramy podczas zjazdu z krawężnika i towarzyszącej temu chwilowej utraty kontaktu jednego z kół z podłożem (wariant B).

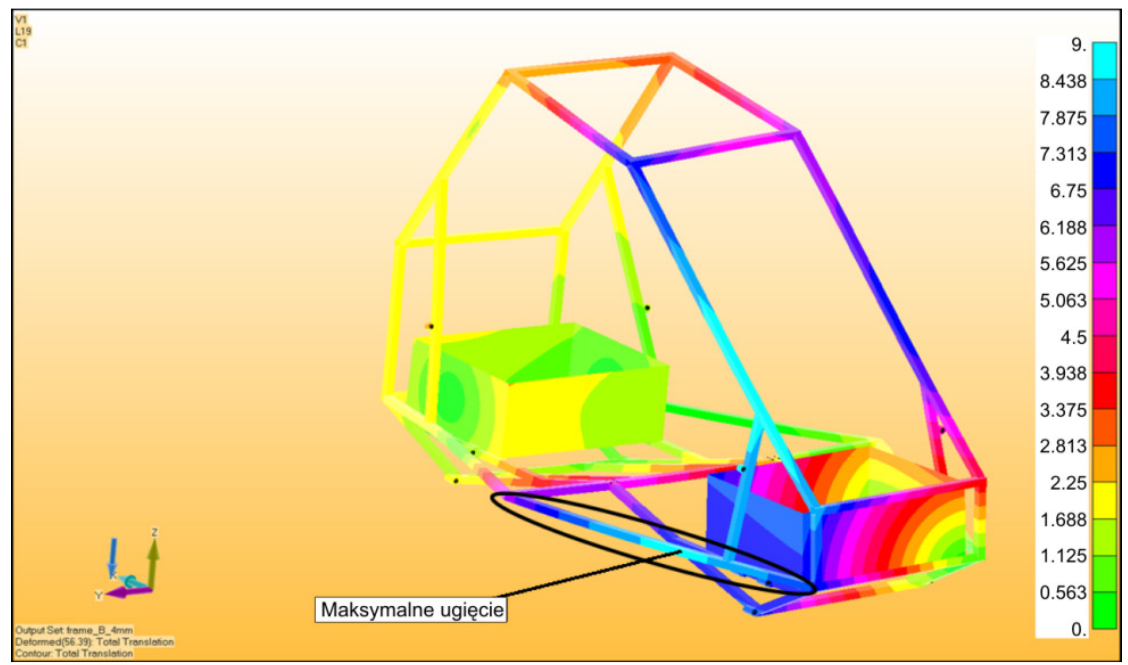

Rysunek 8. Wypadkowe przemieszczenia węzłów dla wariantu B (zjazd z krawężnika) 
Na rysunku 9 pokazano wypadkowe przemieszczenia węzłów oraz wskazano miejsce wystąpienia maksymalnej deformacji pojedynczego profilu ramy dla przypadku najazdu kołem na przeszkodę (wariant D).

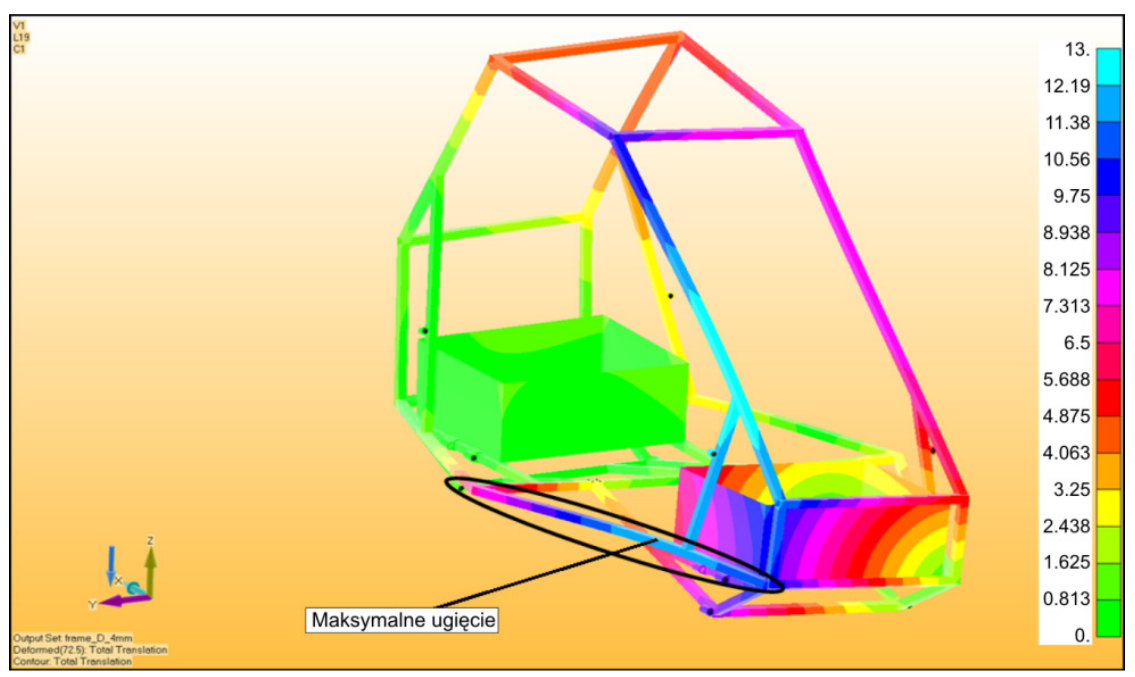

Rysunek 9. Wypadkowe przemieszczenia węzłów dla wariantu D (najazd kołem na przeszkodę)

Z kolei na rysunku 10 przedstawiono te same wielkości w sytuacji gwałtownego hamowania podczas jazdy po wyboistym podłożu (wariant F).

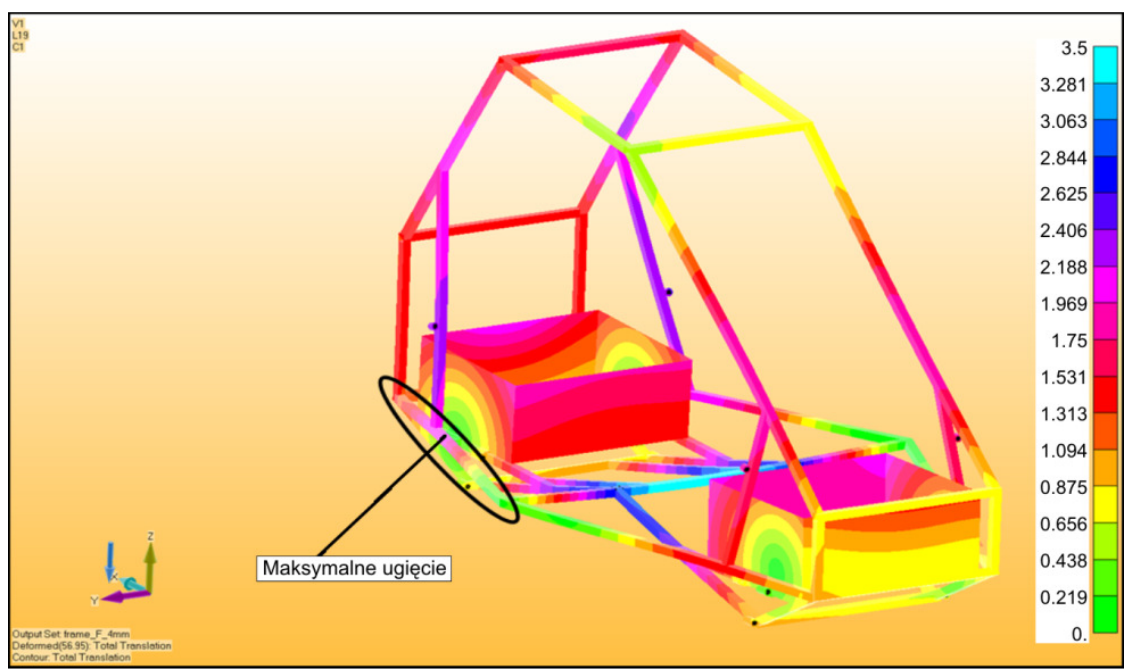

Rysunek 10. Wypadkowe przemieszczenia węzłów dla wariantu F (hamowanie podczas jazdy po nierównościach)

Porównania maksymalnych wartości wypadkowych przemieszczeń węzłów dla wszystkich wariantów obciążeń dokonano na rysunku 11. 


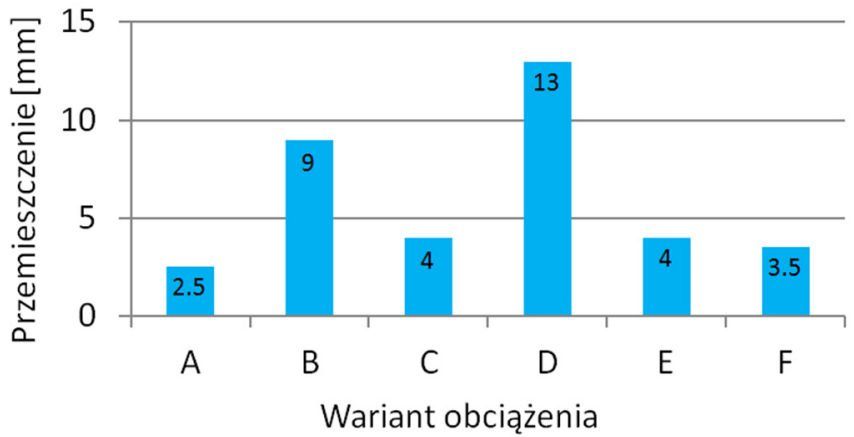

Rysunek 11. Porównanie maksymalnych wartości wypadkowych przemieszczeń węzłów dla rozpatrywanych wariantów obciązeń

Z porównania maksymalnych wartości wypadkowych przemieszczeń węzłów (rys. 11) wynika, że w przypadku wystąpienia bardzo niekorzystnych obciążeń ustroju nośnego, wywołanych utratą kontaktu jednego z kół z podłożem (wariant B) oraz najazdem kołem na przeszkodę (wariant D), następuje duży, lokalny przyrost deformacji struktury. Biorąc jednak pod uwagę odpowiadający tym deformacjom poziom naprężeń, można uznać, że materiał użyty do wykonania ramy został właściwie dobrany.

W celu sprawdzenia sztywności projektowanej ramy, dla każdego z wariantów obciążeń zlokalizowano profil, w którym wystąpiły największe odkształcenia. Odczytane z modelu obliczeniowego wartości maksymalnych ugięć w wybranych profilach porównano następnie $\mathrm{z}$ wartościami dopuszczalnymi (tabela 3). Na podstawie danych $\mathrm{z}$ literatury przyjęto, że dopuszczalna wartość ugięcia pojedynczego profilu $\mathrm{f}=\mathrm{L} / 300$, gdzie L jest długością profilu.

Tabela 3. Porównanie maksymalnych ugięć profili z wartościami dopuszczalnymi

\begin{tabular}{|l|c|c|c|c|c|c|}
\hline \multirow{2}{*}{$\begin{array}{c}\text { Ugięcie profilu } \\
{[\mathrm{mm}]}\end{array}$} & \multicolumn{6}{|c|}{ Wariant obciążenia } \\
\cline { 2 - 7 } & $\mathrm{A}$ & $\mathrm{B}$ & $\mathrm{C}$ & $\mathrm{D}$ & $\mathrm{E}$ & F \\
\hline Wyznaczone & 1.37 & 2.1 & 1.61 & 3.15 & 2.48 & 2.8 \\
\hline Dopuszczalne & 3.83 & 2.33 & 2 & 3.16 & 2.86 & 2.95 \\
\hline
\end{tabular}

W oparciu o otrzymane wyniki (tabela 3) stwierdzono, że odkształcenia poszczególnych profili $\mathrm{w}$ żadnym $\mathrm{z}$ rozpatrywanych wariantów obciążeń nie przekraczają dopuszczalnych wartości.

\section{Podsumowanie i wnioski}

W pracy przedstawiono model obliczeniowy projektowanej ramy przestrzennej (kratownicowej) jednoosobowego pojazdu terenowego o napędzie elektrycznym. 
Analizy numeryczne przeprowadzono w programie FEMAP dla sześciu wariantów obciążenia stanowiących odwzorowanie sił przekazywanych na konstrukcję podczas jazdy w warunkach terenowych. Analizy przeprowadzono w celu sprawdzenia wytrzymałości oraz sztywności projektowanej konstrukcji.

Na podstawie analiz numerycznych stwierdzono, że:

- $\quad$ przyjęta wstępnie grubość ścianek profili użytych do budowy ramy pojazdu nie spełniała przyjętych kryteriów wytrzymałościowych. Analiza numeryczna pozwoliła dobrać taką grubość ścianek profili, która okazała się wystarczająca zarówno z uwagi na wytrzymałość jak i sztywność konstrukcji;

- struktura ramy została tak zaprojektowana, że największe odkształcenia pojedynczych profili $\mathrm{w}$ żadnym $\mathrm{z}$ rozpatrywanych wariantów obciążeń nie przekraczają dopuszczalnych wartości;

- rozmieszczenie akumulatorów w skrzyniach zlokalizowanych z przodu i z tyłu pojazdu okazało się właściwym rozwiązaniem, gdyż pomimo ich znacznej masy nie stwierdzono wystąpienia potencjalnie niebezpiecznych koncentracji naprężeń we wspomnianych lokalizacjach;

- $\quad$ wypadkowe przemieszczenia węzłów (rys. 11) dla wariantów obciążeń B oraz D osiągają wartości, które mogą stanowić przyczynę uszkodzeń poszycia w przypadku zamontowania go na zaprojektowanej w przedstawionej postaci konstrukcji. Aby ograniczyć ryzyko pękania poszycia, należałoby usztywnić ramę poprzez wprowadzenie dodatkowych profili pomiędzy wspornikami amortyzatorów.

\section{LITERATURA}

1. ZIELIŃSKI A.: Konstrukcja nadwozi samochodów osobowych i pochodnych. Wydawnictwa Komunikacji i Łączności, Warszawa 2008.

2. ORZEŁOWSKI S.: Budowa podwozi i nadwozi samochodowych. Wydawnictwo Szkolne i Pedagogiczne, Warszawa 1998.

3. DIN 33408-1 Körperumrissschablonen - Teil 1: Für Sitzplätze, 2008.

4. RUSIŃSKI E.: Mikrokomputerowa analiza ram i nadwozi pojazdów i maszyn roboczych. Wydawnictwa Komunikacji i Łączności, Warszawa 1990.

5. RUSIŃSKI E., CZMOCHOWSKI J., SMOLNICKI T.: Zaawansowana metoda elementów skończonych w konstrukcjach nośnych. Oficyna Wyd. Politechniki Wrocławskiej, Wrocław 2000.

6. NACHIMOWICZ J., PIESIECKI R.: Zastosowanie metod komputerowych do projektowania ram nośnych replik samochodów - obliczenia statyczne. Acta Mechanica Et Automatica, Vol.3, No.1 (2009), 91-94.

7. RUSIŃSKI E.: Zasady projektowania konstrukcji nośnych pojazdów samochodowych. Oficyna Wyd. Politechniki Wrocławskiej, Wrocław 2002.

8. BĄK R, BURCZYŃSKI T.: Wytrzymałość materiałów z elementami ujęcia komputerowego. Wydawnictwa Naukowo-Techniczne, Warszawa 2013. 